\title{
Fifth and fourth millennium BC in north-western Iran: Dalma and Pisdeli revisited
}

\author{
Akbar Abedi 1, Behrooz Omrani 2 and Azam Karimifar 3 \\ 1 Tabriz Islamic Art University, IR \\ akbar.abedi@tabriziau.ac.ir \\ 2 ICHHTO of Tabriz, IR \\ 3 Islamic Azad University of Miyaneh, IR
}

\begin{abstract}
This paper discusses the nature of Dalma and Pisdeli cultures, their regional and interregional interactions and expansions in $5^{\text {th }}$ millennium $B C$. It discusses old and new excavations and surveys as well. According to the importance of the material from these periods found at newly-excavated sites such as Kul Tepe Jolfa, Dava Göz Khoy, Lavin Tepe, and Qosha Tepe, we briefly describe the main stratigraphic and material data from these sites. Old and new data from excavations and surveys eventually lead us to a new chronological table for the $5^{\text {th }}$ millennium BC in north/western (NW) Iran. The implications of the finds are discussed along with their limitations and future research directions.
\end{abstract}

IZVLEČEK - V članku razpravljamo o naravi kultur Dalma in Pisdeli, o njunih regionalnih in medregionalnih interakcijah in širjenju $v 5$. tisočletju pr. $n$. št. Predstavljamo tudi rezultate starih in novih izkopavanj in terenskih pregledov. Na kratko opišemo tudi stratigrafijo in najdbe iz novo izkopanih najdišč Kul Tepe Jolfa, Dava Göz Khoy, Lavin Tepe in Qosha Tepe, ki predstavljajo pomemben material za to obdobje. $S$ pomočjo starih in novih podatkov iz izkopavanj in pregledov smo lahko oblikovali nove kronološke tabele za čas 5. tisočletja pr. n. št. na območju severo-zahodnega Irana. Razpravljamo tudi o implikaciji teh najdb, o njihovih omejitvah in usmeritvah za prihodnje raziskave.

KEY WORDS - Dalma; Pisdeli; ${ }^{14} C$; updated Chalcolithic chronological table; NW Iran

\section{Introduction}

The period between the end of the Hajji Firuz and the beginning of the Kura-Araxes phenomena is one of the least known, yet most important eras in the ancient history and chronology of NW Iran. Previous studies demonstrated that the Chalcolithic is still among the least understood periods of prehistoric development in the region (Hamlin 1975; Dyson, Young 1960; Burney 1964; Pecorella, Salvini 1984; Voigt 1983).

In the $5^{\text {th }}$ and $4^{\text {th }}$ millennium $\mathrm{BC}$, complex societies developed in Eastern Anatolia, Northern (Upper) and Southern (Lower) Mesopotamia. This era, which is often referred to as the 'Post-Ubaid' period, was marked by major structural changes, such as the rise of social hierarchies, technological innovations and economic reorganisation, which eventually led to the emergence of proto-states and cities (Frangipane 2001; Marro 2012; Stien 2012). Some archaeological cultures and traditions that appeared during this period ( $5^{\text {th }}$ millennium) have been brought to light in NW Iran. According to the latest data and material, it is impossible to draw a clear picture of the archaeology of the region during this period. Therefore, the real obstacle is the dramatic lack of absolute dating (with some exceptions), which makes it impossible to define the chronological extent of the Chalcolithic and construct a solid internal periodisation and properly articulated timeline for regional developments in this phase. 
Recent excavations outside Southern Mesopotamia provide a welcome opportunity to rethink the significance of the Post-Ubaid horizon from a different angle: several sites located in the Caucasus (Achundov 2007; 2011; Müseyibli 2007; Lyonnet 2007b; Lyonnet et al. 2008; 2012; Marro 2010; 2012; Helwing 2012), central Anatolia or Cilicia (Caneva et al. 2012) have indeed yielded a number of features that are traditionally associated with the Post-Ubaid horizon: interestingly enough, however, these findings come from settlements whose cultural sequence seemingly developed from a totally different, that is non-Ubaid, background.

Our discussion focuses mainly on two well-excavated sites: Kul Tepe Jolfa at the confluence of the Southern Caucasus, NW Iran and Eastern Anatolia, and Dava Göz Khoy, $5 \mathrm{~km}$ north of the modern town of Dizaj Diz in the Khoy Plain in the Urmia Basin (Fig. 1). Together, these two sites span a chronological range encompassing the Dalma, Pisdeli (LC1 = PostUbaid), and LC2-3, roughly from 5000-3700 calBC. The two sites overlap in the LC1 and LC2 period (c. 4500-3750 calBC). The discussion also draws on data from key contemporaneous sites such as Tepe Lavin, Dagirmen Tepe Bostanabad, Qosha Tepe, Tepe Idir and Köhne Pasgah Tepesi to show the position of NW Iran during the $5^{\text {th }}$ millennium $\mathrm{BC}$ on the basis of new discoveries. The paper also attempts to establish the settlement patterns and the dispersal of archaeological sites in NW Iran at Dalma, Pisdeli, and ChaffFaced Ware/Chaff-Tempered Ware cultures, and highlights some of the fundamental changes that occurred in the structure of $5^{\text {th }}$ millennium sites. The study reviews previous studies in Azerbaijan (NW) in the form of archaeological excavations, surveys and data recovered in the aftermath of Iran's Islamic Revolution. As such, new surveys at NW not only explain the causes of changes in socio-cultural patterns, but also clarify the undisclosed archaeological situation in eastern parts of Lake Urmia, and help to complete the Chalcolithic chronological table and the distribution map of the region during the periods mentioned. in NW Iran.
In our discussion, we prefer to use the important modified LC1-5 chronological terminology (Rothman 2001.5-9) as proposed by Gil Stein and Catherine Marro (Stein 2012; Marro 2012), and specific local sequences in order to avoid projecting a Southern Mesopotamian chronology and modes of organisation onto northern regions which developed social complexity through processes that were largely, if not completely, indigenous and different from those that characterised Southern Mesopotamia.

\section{A history of archaeological research in NW Iran}

The initial excavation in north-western Iran was made by Frank Earp, who opened four Bronze Age tombs in 1903 (Crawford 1975), and Theodore Burton Brown, who spent six weeks excavating eight separate trenches at Geoy Tepe in western Lake Urmia in 1948 (Burton-Brown 1951). Their work continued, with new methodologies, by Charles Burney, whose work focused on the very famous Yanik Tepe site. With his excavations at Yanik Tepe, Burney produced the first evidence for the appearance of the Kura-Araxes culture in north-western Iran (Burney 1961a; 1961b; 1962; 1964; see also Summers 2013a-b).

Long-term archaeological investigations in north-western Iran continued at other sites, such as Hasanlu in the western Lake Urmia region, directed by Robert Dyson (Dyson 1965; 1968; 1972; Dyson, Muscarella

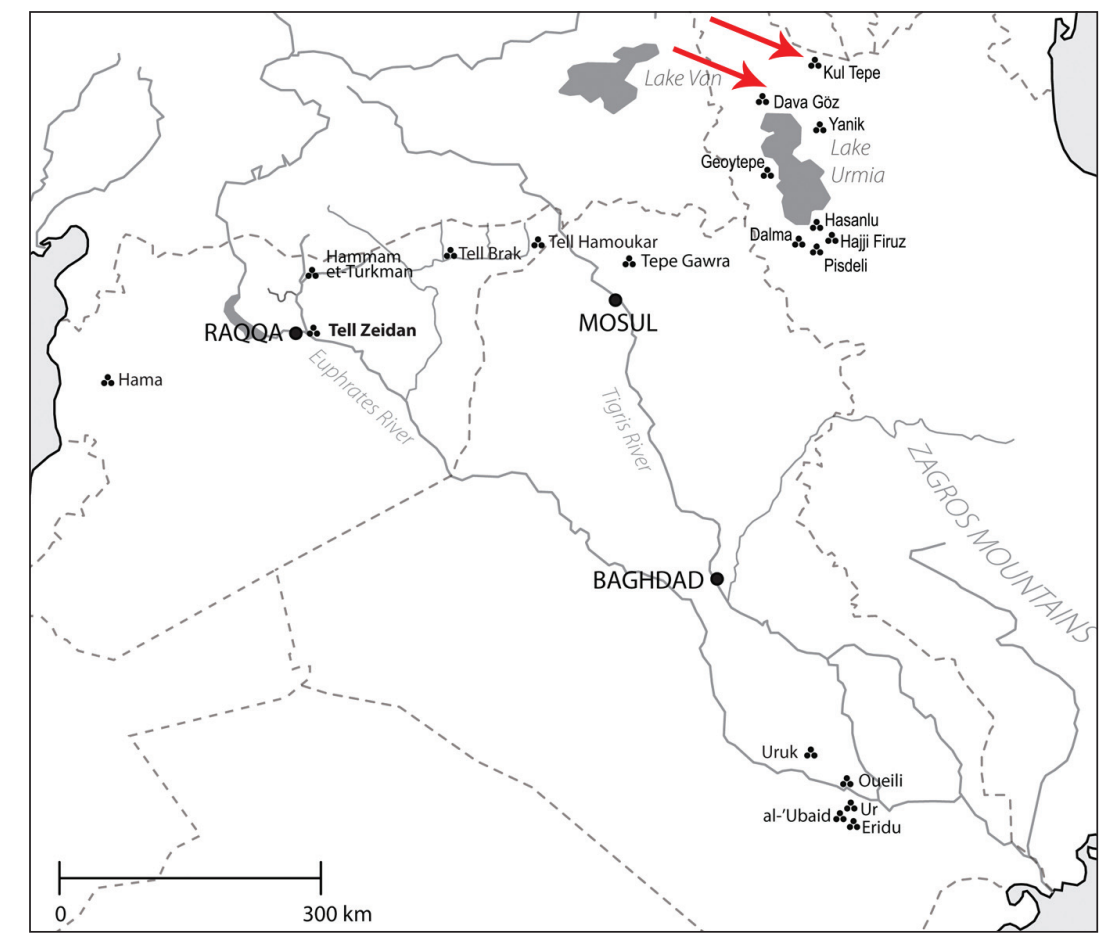

Fig. 1. Map showing the locations of Kul Tepe Jolfa and Dava Göz Khoy 
1989), Hajji Firuz (Voigt 1983), Dalma (Hamlin 1975) and Pisdeli (Dyson, Young 1960). Studies subsequent to these early excavations led to the identification of the Late Neolithic period in Hajji Firuz (6th millennium $\mathrm{BC}$ ), previously regarded as belonging to the cultural horizon of Hasuan in Mesopotamia (Voigt 1983). Chalcolithic cultural material excavated at Dalma (5000-4500 calBC) was also comparable with that of the Halaf and Ubaid cultures in Southern Mesopotamia (Oates 1983). The Dalma period was followed by Pisdeli Culture (4500-3900/ 3800 calBC), which was contemporaneous with the Late-Ubaid/Post-Ubaid horizon. Geoy M/Gijlar C culture (4000-3500 calBC) is the final phase of the Chalcolithic period in north-western Iran, excavated and reported from Gijlar, Geoy M and Trench M at Yanik Tepe (Helwing 2004). The material culture of Yanik (Kura-Araxes), which takes its name from the Bronze Age Yanik Tepe site, belongs to the early Trans-Caucasian or Kura-Araxes culture (second half of the $4^{\text {th }}$ to end of the $3^{\text {th }}$ millennium $\mathrm{BC}$ ), which spread through the Caucasus and the Urmia Basin. Its origin is unknown, but it has been observed in the valleys and foothills of three Caucasian republics (Azerbaijan, Armenia and Georgia), as well as north-western and western Iran, eastern Anatolia and the Levant (Sagona 1984; Kushnareva 1997; Rothman 2003; Batiuk 2005; Kohl 2007; Gopnik, Rothman 2011; Batiuk 2013; Abedi et al. 2014). During the final phase of prehistory in north-western Iran, the Middle and Late Bronze Age culture (2200/2000 to 1500 calBC) known as Urmia Ware, including painted monochrome and polychrome pottery, prevailed in this region. In the first half of the $2^{\text {nd }}$ millennium $\mathrm{BC}$, Urmia Ware extended over the Urmia basin and has been found in Haftavan VIB (Edwards 1981; 1983; 1986). Despite the general similarity between Urmia pottery, different regional names are used; for example, in eastern Georgia, pottery of this type is known as Trialeti-Vanadzor culture (Smith et al. 2009), in Azerbaijan as Uzarlik culture (Kushnareva, Lisitsyna 1980), and in Armenia as Karmirberd-Sevan culture (Abedi et al. 2009).

In addition to the above-mentioned projects in northwestern Iran, other excavations and surveys carried out during recent decades in the Lake Urmia basin included Geoy Tepe (Burton-Brown 1951), Kordlar Tepe (Kromer, Lippert 1976; Lippert 1976), Tepe Dinkha (Dyson 1967a; Hamlin 1974), Haftavan Tepe (Burney 1970a; 1970b; 1972; 1973; 1974; 1975; 1976a; 1976b; 1979a; Edwards 1981; 1983; 1986), Tepe Ahranjan (Tala'i 1983), Tepe Gijlar (Pecorella, Salvini 1984; Belgiorno et al. 1984), Kul
Tepe of Marand (Kroll 1990), and Gol Tepe (Tala'i 1984). In addition, surveys were undertaken in northwestern Iran (Kambakhsh Fard 1967; Soleki 1969; Soleki, Soleki 1973; Swiny 1975; Pecorella, Salvini 1984), the Salmas valley (Kearton 1969; 1970) and the Solduz plain (Dyson 1967b), around Lake Urmia (by a German team) (Kleiss, Kroll 1979; 1992; Kroll 1984; 2005) and in the Meshkin Shahr area (Burney 1979b; Ingraham, Summers 1979). Since the 1979 Revolution in Iran, archaeological research has included Early Bronze Age settlement patterns and site distribution in north-western Iran (Omrani 2006; Omrani et al. 2012; Summers 2013a), a survey in Eastern Azerbaijan province (Khatib Shahidi, Biscione 2007; Biscione, Khatib Shahidi 2006), a systematic survey at Tepe Baruj (Alizadeh, Azarnoush 2003a; 2003b) and the Mughan plain (Alizadeh, Ur 2007), and excavations at Lavin Tepe (Nobari et al. 2012), Nader Tepesi (Alizadeh 2007), Qosha Tepe in the Meshkin Shahr area (Nobari, Purfaraj 2005), Kohne Pasghah Tepesi (Maziar 2010), the Iron Age cemetery of Masjed Kabood in Tabriz (Nobari 2000 [1379]; 2004 [1383]), the Qale Khosrow and Ardebil Survey (Azarnoush et al. 2006), Qalaychi and Tepe Rabat (Kargar 2005; Kargar, Binandeh 2009), Zardkhaneh of Ahar (Niknami 2011), and Köhne Shahar (Ravaz) (Alizadeh et al. 2015). Apart from these excavations and surveys, many others have yet to be published.

The main problems for archaeology in north-western Iran are the lack of systematic and intensive longterm excavations and surveys and a shortage of reliable publications, as well as inaccurate and uncalibrated dating of old excavations and a shortage of multidisciplinary works. In recent years, most excavations in north-western Iran have taken place in the course of salvage and dam construction projects.

\section{Kul Tepe Jolfa and Dava Göz Khoy in NW Iran}

\section{Kul Tepe Jolfa}

The Kul Tepe site (E 45 39' 43"- N 38 50' 19", $967 \mathrm{~m}$ a.s.1.; Figs. 1-2) is located near the city of $\mathrm{Ha}-$ dishahr, $10 \mathrm{~km}$ further to the south of the Araxes River. Kul Tepe is a multi-period tell, about 6ha in extent and rising $19 \mathrm{~m}$ above the surrounding land. The site was originally discovered by an expedition in the province of East Azerbaijan in 1968 under the supervision of Sayf Kambakhsh Fard (Kambakh Fard 1968), and was later reported by other authors as well (Kliess, Kroll 1992; Kroll 1884; Edwards 1986; Omrani 1994). Kul Tepe is located precisely in the north-western corner of Iran, which is the 
gateway between the Southern Caucasus and northwestern Iran, about $50 \mathrm{~km}$ from the famous Kültepe site at Nakhichevan. Kul Tepe is located next to a broad valley, at the centre of the highlands and at the crossroads of major routes linking the Iranian plateau to Anatolia and the Caucasus to Northern Mesopotamia (Fig. 1). This strategic location is further enhanced by the region's wealth in natural resources, which include rich copper and salt deposits. The first season of excavation at Kul Tepe were carried out from June to August in 2010 (Abedi et al. 2014). Because of the huge quantity of material and deposits at Kul Tepe, the site needs more research and excavation to better understand the cultural situation in the region. The second season of excavation was from August to October 2013 in order to answer certain questions about the region and extend the studied areas.

The first and second seasons of excavation were primarily aimed at clarifying the chronology and settlement organisation, and answering some fundamental questions (such as the transition process from the Late Chalcolithic to the Early Bronze Age), identifying different cultural horizons, including the ProtoKura-Araxes and Kura-Araxes I periods, and also outlining the cultural situation in the region during prehistoric and historical periods. The initial aims were to establish periods of occupation and to obtain a stratigraphically controlled ceramic sequence for the Jolfa region and the northern part of north-western Iran. More specifically, Kul Tepe, was excavated for two main reasons:

\begin{tabular}{|c|c|c|}
\hline $\begin{array}{l}\text { Kul Tepe } \\
\text { periods }\end{array}$ & Cultural phases & $\begin{array}{l}\text { Range } \\
\text { (calBC) }\end{array}$ \\
\hline VIII & $\begin{array}{c}\text { Early Chalcolithic (Dalma) } \\
3 m \text { deposit }\end{array}$ & $5000-4500$ \\
\hline VII & $\begin{array}{c}\text { LC1: Pisdeli/Hasanlu VIII } \\
\text { 1.5m deposit }\end{array}$ & $4500-4200$ \\
\hline VIB & $\begin{array}{l}\text { LC2: Chaff-Faced } \\
3 m \text { deposit }\end{array}$ & $4200-3900$ \\
\hline VIA & $\begin{array}{l}\text { LC3: Chaff-Faced } \\
3 m \text { deposit }\end{array}$ & $4000 / 3900-3750$ \\
\hline V & $\begin{array}{c}\text { Kura-Araxes I } \\
3.5-4 \mathrm{~m} \text { deposit }\end{array}$ & $3400 / 3350-3100 / 3000$ \\
\hline IV & $\begin{array}{c}\text { Kura-Araxes II, III } \\
7.5-8 \mathrm{~m} \text { deposit }\end{array}$ & $3000 / 2900-2500$ \\
\hline III & $\begin{array}{c}\text { Middle Bronze Age (Urmia Ware) } \\
\text { Im deposit }\end{array}$ & $7^{\text {st }}$ half of $2^{\text {nd }}$ millennium \\
\hline II & $\begin{array}{l}\text { Iron Age III, Urartian } \\
50 \mathrm{~cm} \text { deposit }\end{array}$ & $8^{\text {th }}-6$ th century \\
\hline I & $\begin{array}{l}\text { Achaemenid } \\
\text { Im deposit }\end{array}$ & $6^{\text {th }}-4^{\text {th }}$ century \\
\hline
\end{tabular}

Tab. 1. Sequence at Kul Tepe based on excavations in 2010 and 2013.
(1) to determine the presence of Late Chalcolithic followed by Early Bronze Age occupation levels; 2 more importantly, to test for the presence of a probable 'transition' period between the Late Chalcolithic and Early Bronze Ages and the existence of Proto-Kura-Araxes and Kura-Araxes I periods.

Based on the results of the first and second seasons of excavation, eight main periods were identified, which provide evidence of a continuous sequence (except in the Iron Age I and II periods) and significant material was found from the Dalma (Period VIII), Pisdeli (= LC1: Period VII), Chaff-Faced Ware horizons (LC2-3: Period VIB and VIA), Kura-Araxes I (Period V), Kura-Araxes II (Period: IV), Middle Bronze/ Late Bronze Age (Urmia Ware, Period: III), Iron III (Period II), and Urartian/Achaemenid (Period I) periods. As a result of the excavation of $24 \mathrm{~m}$ deposits it was established that it consists of $3 \mathrm{~m}$ deposit of Dalma, $1.5 \mathrm{~m}$ of Pisdeli, $6 \mathrm{~m}$ of CFW horizon (Kul Tepe VIB and VIA), 3.5-4m of Kura-Araxes I, 7.5-8m of Kura-Araxes II, $1 \mathrm{~m}$ of Middle and Late Bronze Age with typical Urmia Ware and finally $1.5 \mathrm{~m}$ of Iron III with Urartian and Achaemenid materials (Abedi, Omrani 2013; Abedi et al. 2014) (Figs. 3-4, Tab. 1).

Interestingly, Mary Voigt and Robert Dyson, based on Pisdeli Tepe materials and site sequence, suggested a transition between the Dalma and Pisdeli periods, with no gap between them. They proposed that Pisdeli culture developed locally (Voigt, Dyson 1992. 174). The Kul Tepe excavation supports this notion. Late Chalcolithic layers were discovered in the deep sounding, in Trench III, with no break after the Dalma (Fig. 5) materials. Based on pottery type, form, design and surface treatment and the sequence in which they occur, and on other Late Chalcolithic materials at Kul Tepe, three sub-phases were identified: Kul Tepe VII = Pisdeli $(\mathrm{LC1}=$ Post-Ubaid $)$, Kul Tepe VIB = LC2 (Chaff-faced/ Chaff-tempered), and Kul Tepe VIA = LC3 (Chaff-tempered) cultures.

The lowest Late Chalcolithic layers (LC1, Post-Ubaid: 4500-4200 calBC) include black-on-buff, so-called Pisdelitype painted pottery. This pottery repertoire is almost entirely limited to geometric or non-representational designs; emphasis is on horizontal banding made with straight lines, which may border some design elements. All 


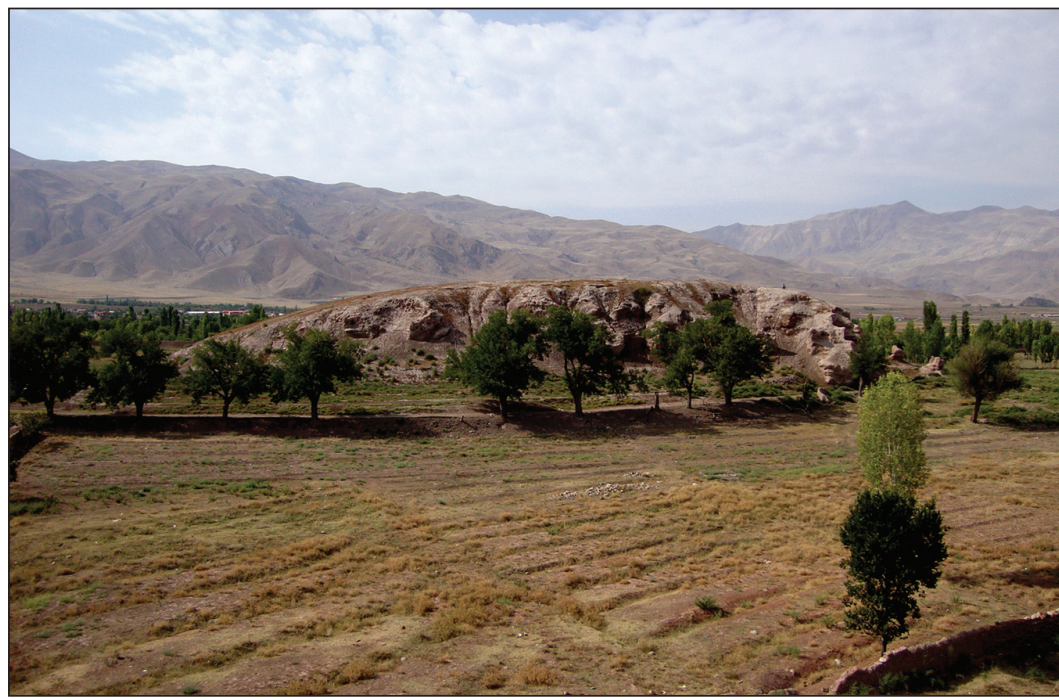

Fig. 2. General view of Kul Tepe, view from the north.
calBC), termed Kul Tepe VIB, and $\mathrm{LC} 3=$ Chaff-faced Ware (3900-3700 calBC), termed Kul Tepe VIA. According to the stratigraphic section in the upper part of Trench III and the lower part of Trench II, $6 \mathrm{~m}$ of deposits relate to Kul Tepe periods VIB (LC2) and VIA (LC3) (Fig. 7).

The chronological framework presented here is based on three lines of evidence: (1) rim and decoration typology (embedded within the stratigraphic sequence), (2) pottery technology, (3) radiocarbon dates. the painted pottery of this period bears monochrome and matte paint, with colours ranging from brown to black. Generally, painting is limited to bowls and small pots. Most of the pottery of the Late Chalcolithic consists of buff to reddish chaff-tempered fabric. All of the painted sherds are painted black and brown on buff or brown and red (reddish-brown), and include geometric designs such as oblique and diagonal lines beneath the rim. Another diagnostic design is hatched and plaid on jars and bowls (Fig. 6).

Late $5^{\text {th }}$ millennium Chaff-Faced Ware appears alongside Ubaid-related (Pisdeli) black on buff during LC 2-3. Two main periods can be distinguished, mainly based on ceramic evidence, but supported by additional information from other kinds of artefact. These periods are LC2 $=$ Chaff-faced Ware (4200-3900

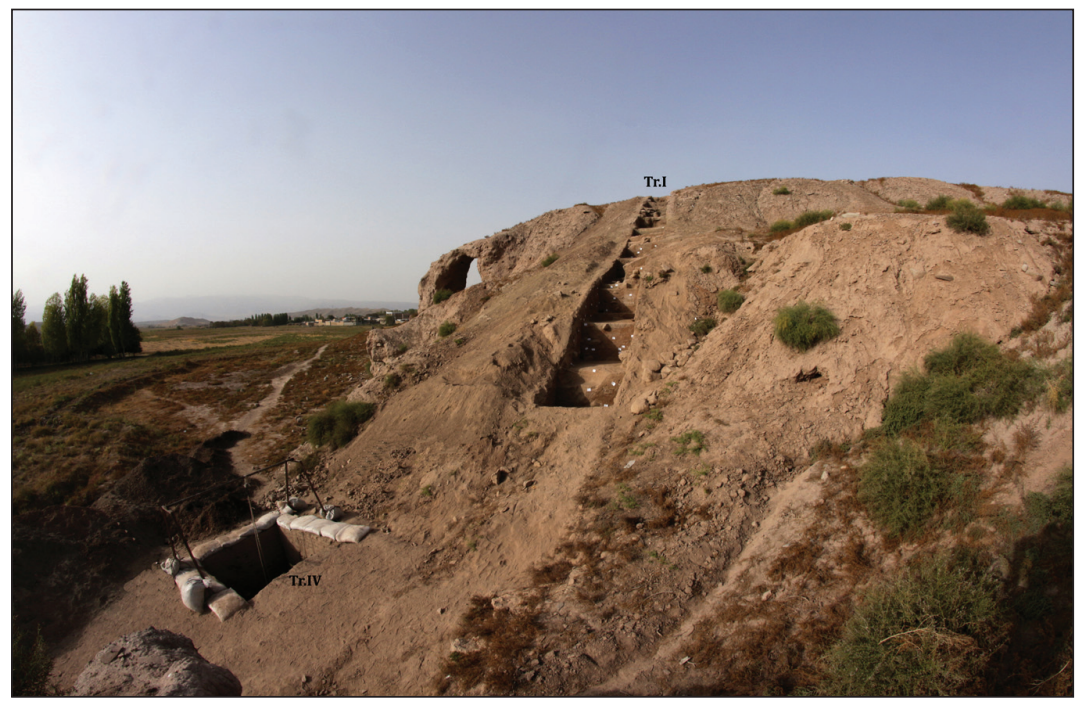

Fig. 3. Kul Tepe. Stratigraphic sections of trench I and IV small-scale excavations.
Late $5^{\text {th }}$ millennium Chaff-faced or Chaff-tempered ware appears alongside Ubaid-related black on buff during LC 2-3 (Helwing 2012). In the later phase of the Chalcolithic, most of the pottery production is buff, chaff-tempered and chaff-faced. The repertoire of shapes consists mainly of simple everted bowls, pots and jars, sometimes decorated with a row of bosses below the rim or an annular coil around the shoulder. Rims decorated with incisions or impressions are common to most pottery of this LC2 and 3 type at this site.

Chaff-faced and chaff-tempered pottery with combed surfaces is typical of the Late Chalcolithic of Southern Azerbaijan in general and the Nakhichevan region and north-western Iran in particular, where it has been termed 'Kültepe culture'. Similar pottery was found at Kültepe I, Khalaj, Erebyengicesi, Sederek (Bakhshaliyev et al. 2009; Marro et al. 2011), Kul Tepe of Marand (Kroll 1990), Tepe Baruj (Alizadeh, Azarnoush 2003b) and Tepe Dava Göz Khoy (Abedi, Omrani 2013). But close comparisons may also be made over a much wider area, which includes Eastern Anatolia, the Urmia basin and Northern Mesopotamia, where similar traits are designated as part of the 'Marand culture' in Iran (Kroll 1994), or 'Chaff-faced ware culture', also called 'Amuq (E)-F', in Turkey and Northern Syria (Braidwood, Braidwood 1960). 


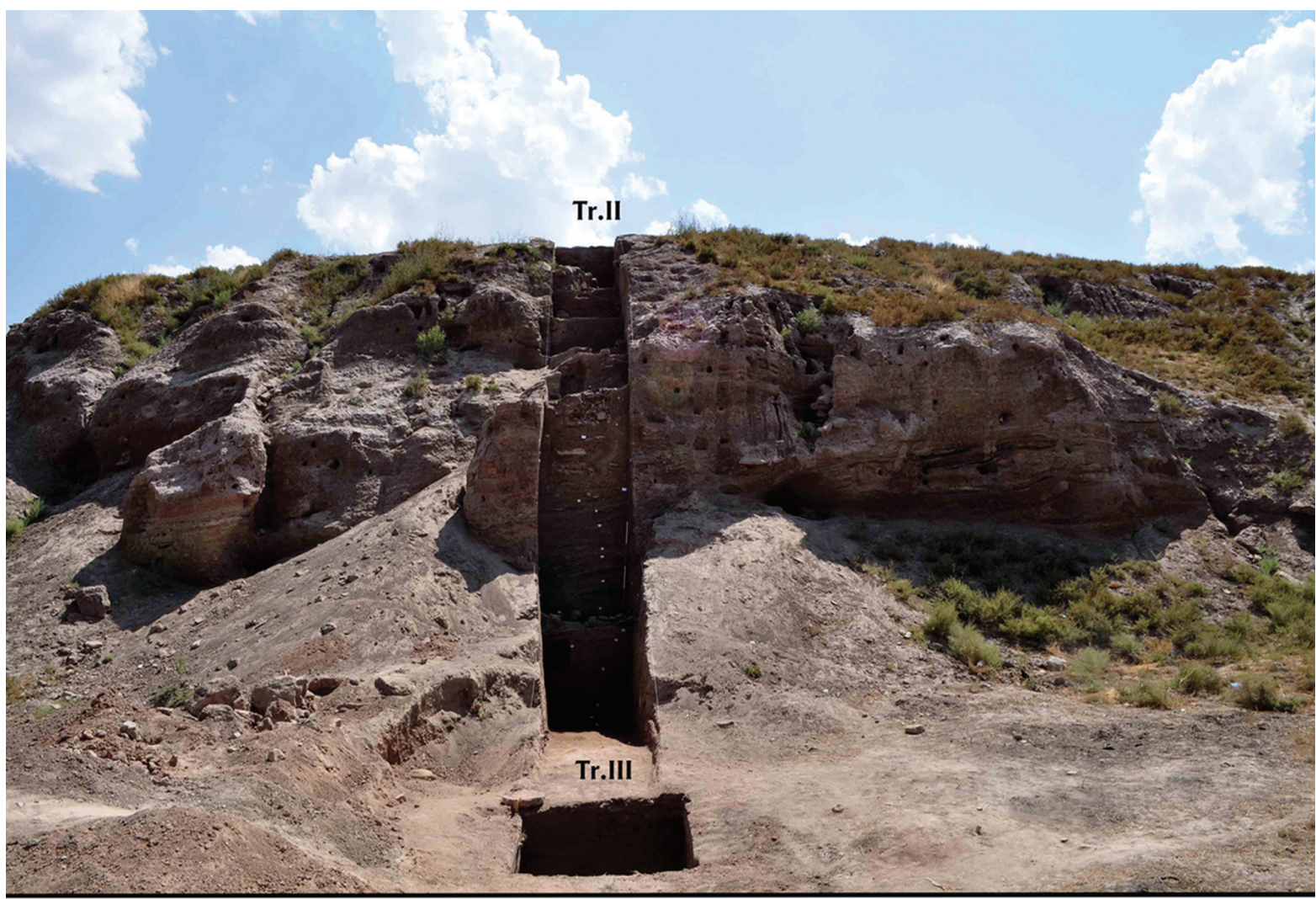

Tr. III

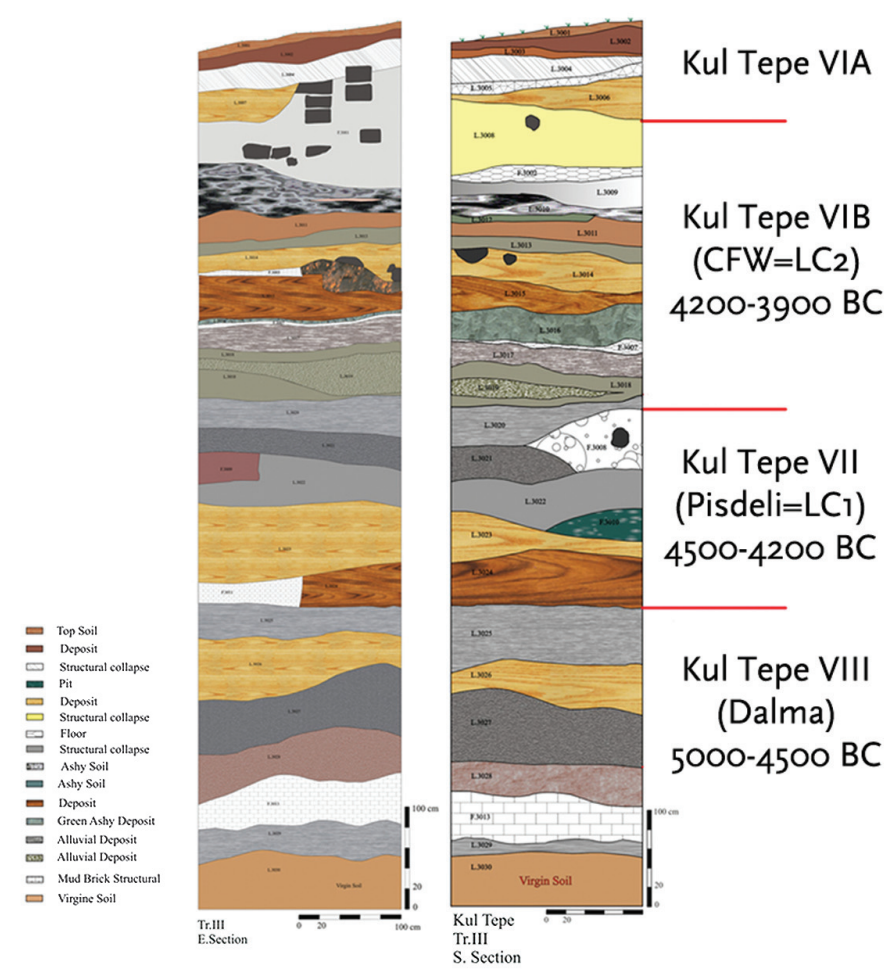

Tr. II

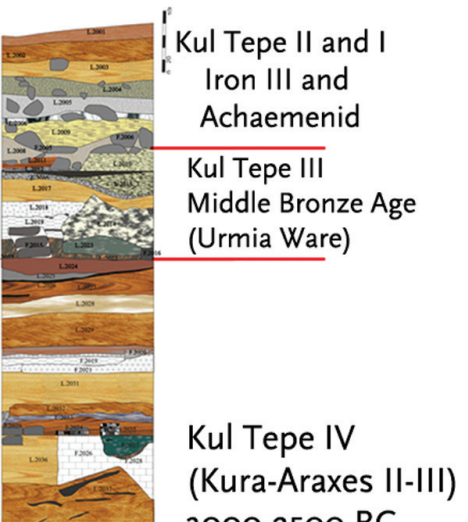

3000-2500 BC
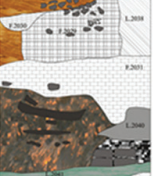

Kul Tepe $\mathrm{V}$

(Kura-Araxes I)

3400/3350-3100-3000 BC
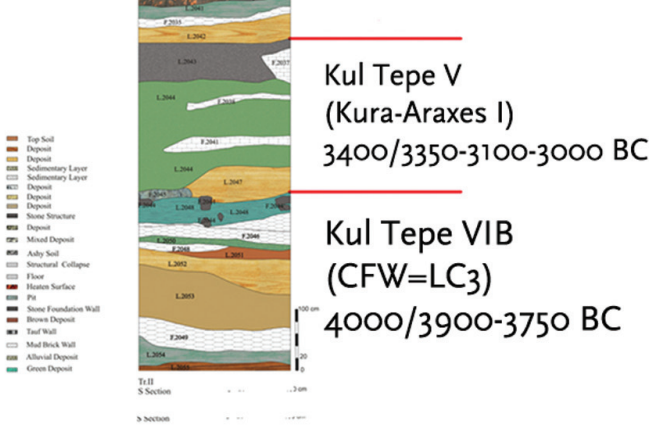

Fig. 4. Kul Tepe. Step trench II and deep trench II; stratigraphic section of trench II and III soundings. 
However, if we focus on the main features of the pottery assemblage from Kul Tepe, it is clear that this repertoire shares close similarities with sites located in the northern parts of the Araxes River, especially sites like Ovçular Tepesi, Kültepe, Alikömek Tepesi, Mentesh Tepe and Leila Tepe in Azerbaijan, Sioni and most related sites in Georgia, Aratashen in Armenia, and some sites in eastern Turkey and northern Mesopotamia.

\section{Dava Göz}

The settlement of Dava Göz is situated about $10 \mathrm{~km}$ south-west of Khoy and 5km north of Dizaj Diz town. Dava Göz is a small site, measuring about $100 \times 100 \mathrm{~m}$ (approx. 1ha). The site has been completely destroyed by modern agricultural activities, which prevents mapping of the whole topography (Fig. 8). The stratigraphy of the settlement is now well understood, and covers the Late Neolithic/Transitional Chalcolithic (Hajji Firuz/Dava Göz I = Period I) and Chalcolithic $($ Pisdeli $=\mathrm{LC1}=$ Period II and CFW horizon $=$ LC2 = Period III) phases of the regional culture north of the Lake Urmia basin (Fig. 9-10). The first season of excavation at Dava Göz lasted from June to August 2012. Dava Göz is a horizontal site that relates to the Hajji Firuz, Dava Göz (Transitional Chalcolithic), Pisdeli and CFW cultures. Hajji Firuz materials are mainly located at the centre of the site. It seems clear that during Hajji Firuz Period this was seasonal camp site, because the layers are no more than $0.5 \mathrm{~m}$ thick. However, the Pisdeli materials were mainly in the western part of the site, with a cultural layer of $2.5-3 \mathrm{~m}$.

Actually, Dava Göz is one of the few well-excavated settlements to yield new information on developments in the Lake Urmia basin communities between the $6^{\text {th }}$ to $4^{\text {th }}$ millennium $\mathrm{BC}$, and on their relationships with contemporary Caucasian cultures, as well as with those located further west and south in Eastern Anatolia and in the Syro-Mesopotamian region.

Dava Göz overlaps in the LC1 and 2 periods with Kul Tepe VII and VIB (c. 4500-3900 calBC). Like Kul Tepe, the Dava Göz pottery repertoire is divided into two, painted and unpainted, through LC 1 and 2. The pottery assemblage is the same as at Kul Tepe and encompasses cultural layer at the site (Fig. 10).

\section{$5^{\text {th }}$ millennium BC and the problem of chrono- logy in NW Iran}

Obviously, the (absolute and relative) chronology and internal periodisation of the Chalcolithic period have been, and still are, the subject of much research and debate. It would appear that the difficulties encountered in establishing the chronological time limits of this cultural phenomenon, which still continue to fluctuate, are mainly due to the dearth of absolute dating in the Southern Caucasus (with only a few exceptions), while over the course of time there seems to have been a general tendency, supported by new dating, to shift the time limits of (or at least the starting time) higher up the time scale.

After three decades of stagnation in archaeological activities in NW Iran, valuable work has been done in recent years. Almost all the excavated sites in this region are situated around the Lake Urmia, while information about other parts of the region is lacking, and different parts of the region and its prehistory have received unequal attention. While a considerable area of the western and southern parts of the Lake Urmia basin has been explored relatively comprehensively, eastern and northern parts remain largely archaeological terra incognita.

Previous studies put the Dalma period in the second half of $5^{\text {th }}$ millennium BC (Hamlin 1975; Hole 1987), although only one date was available from this period (Hole 1987). The rare scientific excavations carried out concerning the Dalma period in its homeland (NW Iran) with only one ${ }^{14} \mathrm{C}$ date has limited our ability to establish a solid chronological table for the whole of the Dalma period. The same limitation has also risen for the Pisdeli period, for which only rare radiocarbon dates are available, and with an imprecise and faulty time span (late $5^{\text {th }}$ to early $4^{\text {th }}$ millennium BC). Prior to the Kul Tepe Jolfa and Dava Göz Khoy excavations, it was not possible to establish appropriate and precise periodisation and chronology between Hasanlu VIII and VII in the chronological sequence of NW Iran (Tab. 2).

The $5^{\text {th }}$ millennium is considered as the largest lacuna in our understanding of the developmental sequence in NW Iran, although new excavations with absolute radiocarbon dates have shed some new light on the Chalcolithic period in the region.

\section{Dalma period in NW Iran (5000-4500 BC)}

In the first half of the $5^{\text {th }}$ millennium BC (Early Chalcolithic), the remarkably homogeneous Dalma ceramic assemblage spread throughout much of northwest and western Iran. Dalma is an unusual ceramic phenomenon for this time range: a widespread, but technically and stylistically homogeneous material cultural tradition, at home in a topographically severe highland region. The Dalma period is particu- 


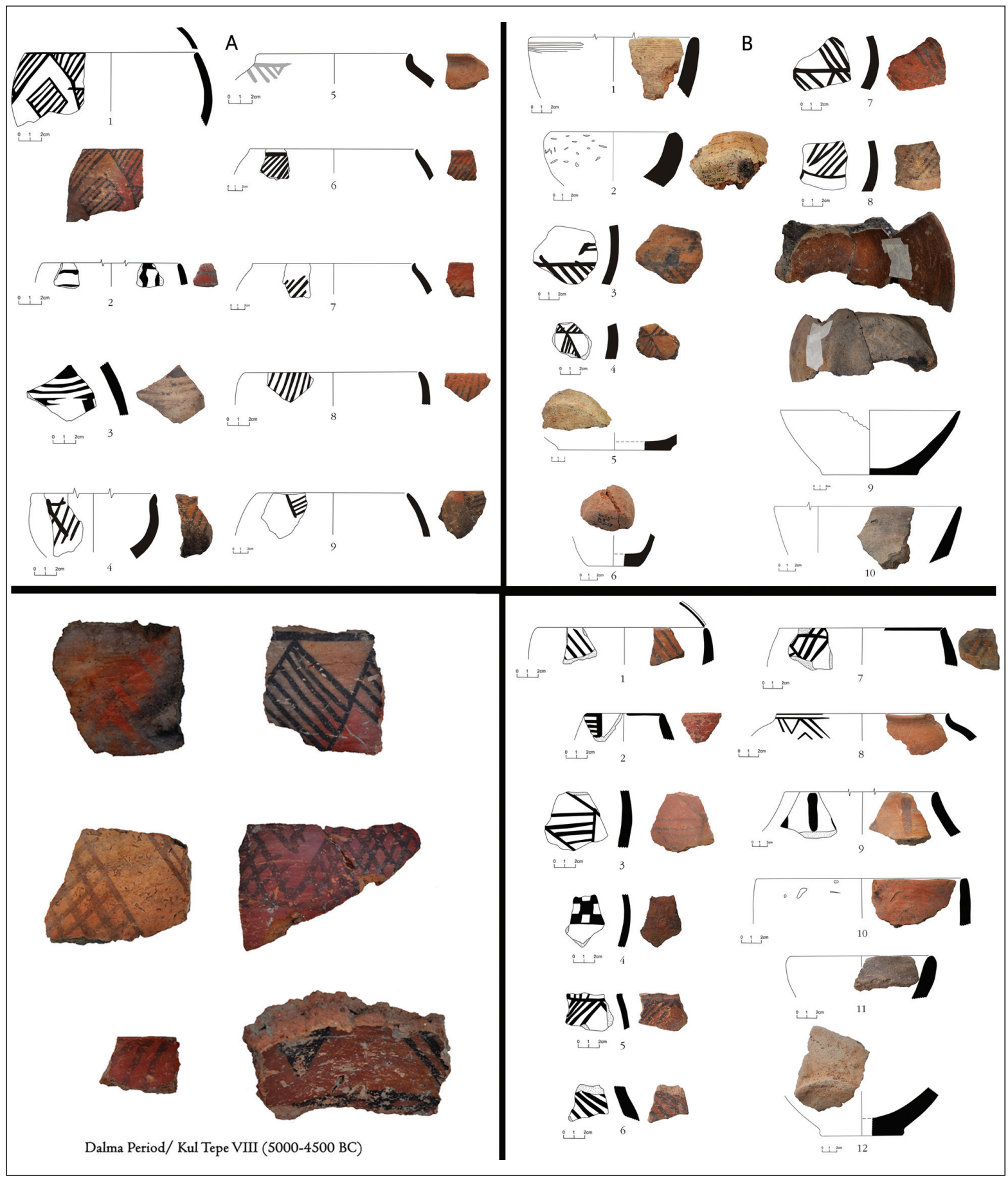

Fig. 5. Kul Tepe VIII (Dalma) pottery, Tr. III and IV.

larly interesting because of the extremely large geographic spread of its ceramics, ranging from the 'widely separated mountain plains such as the Urmia basin and the Mahidasht and the Kangavar regions' to the Hamrin region of eastern Iraq, where it occurs in combination with typical Halaf and Ubaid pottery. Similar ceramic types have also been found in the Caucasus Mountains. The first evidence of Dalma culture was found at the south-west end of Lake Urmia, at Tepe Dalma and Hasanlu in 1958. Dalma materials have also been reported from Hajji Firuz, Pisdeli and Tepe Seavan. Apart from the mentioned excavations, various surveys have been carried out by different expeditions (Dyson 1962; Hamlin 1975; Henrickson, Vitali 1987; Hole 1987; Levine, Young 1987; Solecki, Solecki 1973; Vandiver 1985; Voigt, Dyson 1992; Young, Levine 1974; Pecorella, Salvini 1984; Kroll 1984; 1994; Tonoike 2009; Vitali, Henrickson 1987; Hamlin 1975; Hole 1987b; Oates 1983.261; Voigt, Dyson 1992). 


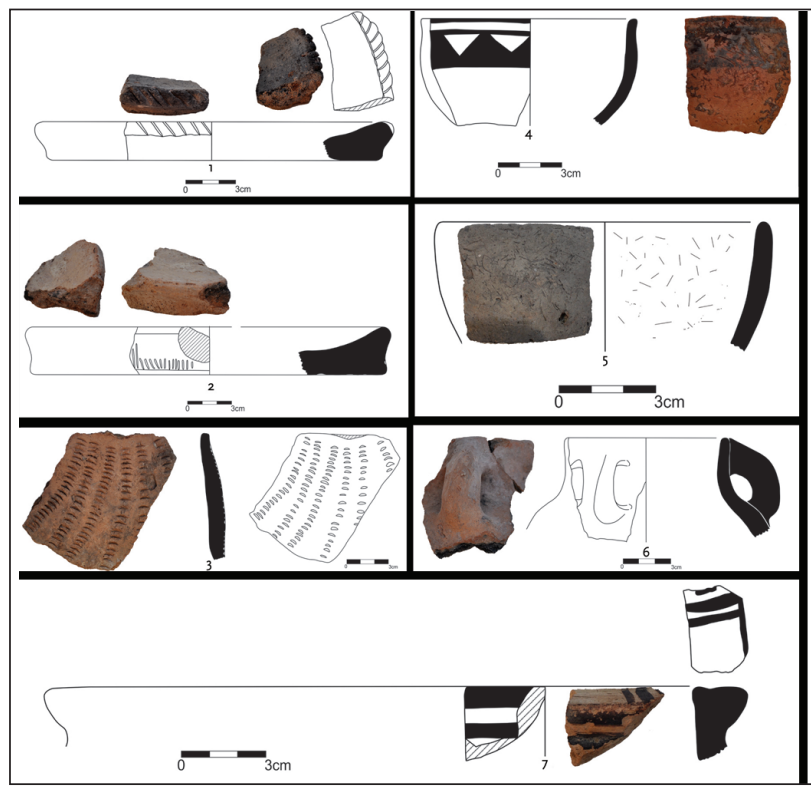

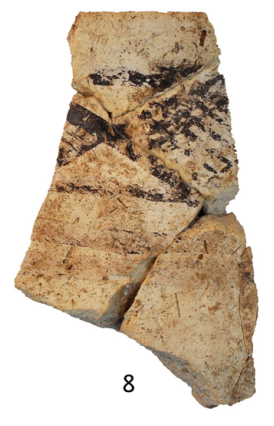

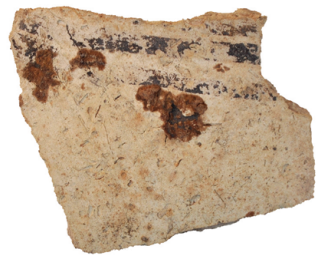

9
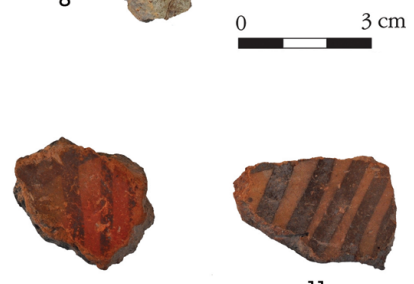

10

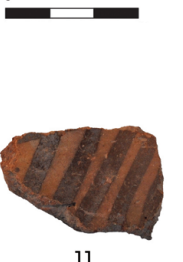

Fig. 6. Kul Tepe VII (LC1) Pisdeli type pottery.

The series of radiocarbon dates now available from Kul Tepe Jolfa, Tepe Dava Göz and one calibrated date from Tepe Dalma, make it clear that the frequently mentioned date of $4215 \pm 84$ calBC from Tepe Dalma (second half of $5^{\text {th }}$ millennium), and suggested dates of 4100-3700 calBC for Dalma culture said to date the Middle Chalcolithic, are much too recent in NW Iran and should now be revised (Hamlin 1975; Voigt, Dyson 1992; Henrickson 1985.70). New radiocarbon dates from Kul Tepe Jolfa and Dava Göz suggest the first half of the $5^{\text {th }}$ millennium calBC for the Dalma period in NW Iran (5000-4500 calBC) (Abedi et al. 2014; Abedi, Omrani 2013). The available dates argue that the Dalma tradition flourished during first half of the $5^{\text {th }}$ millennium calBC in NW Iran, spreading south to the Central Zagros in the second half of $5^{\text {th }}$ millennium.

Valuable work has been done on prehistoric archaeology in Iranian Azerbaijan in the form of archaeological excavations, surveys and data recovered in the aftermath of Iran's Islamic Revolution. Recent excavations at Kul Tepe Jolfa (Abedi et al. 2014; 2009), Tepe Ahranjan (Talai 1983; Kargar 1994), Tepe Lavin (Nobari et al. 2012), Qosha Tepe (Nobari, Purfaraj 2005), Tepe Idir (Hesari, Akbari 2007), and Tepe Baruj (Alizadeh 2001; Alizadeh 2003a; 2003b) have yielded fascinating new information about Dalma culture. Apart from these excavated sites, more than 100 Dalma and Dalma-related sites have been brought to light by old and recent surveys in NW Iran.

Recently, scholars have suggested a combination of factors, such as trade and exchange, the movement of material goods and information, migration, diffusion, and local emulations of foreign styles to explain Dalma cultural phenomena (Voigt 1983; Tonoike 2009). The settlement pattern and distribution of Dalma sites in NW Iran suggests it can be divided into two types: (1) permanent settlements in fertile inter-mountain valleys, and (2) temporary seasonal camp sites in the highlands of Zagros, the Caucasus and other highlands of north-west Iran. Yukiko Tonoike (2009) concluded that a village-based form of seasonal migration (transhumant pastoralism) was the most likely scenario, whereby small groups of nomads moved between villages with which they maintained relationships, possibly through kinship. Transhumance is a specialised form of pastoralism that is still based on permanent settlements, but involves the seasonal movement of the herd between pastures (Abdi 2003).

What is important in this respect is the chronological differences between north-western Iran and the Central Zagros regions, where the Dalma period ranges from 4100 to 3700 calBC, whereas this time coincides with the LC 2 and 3 (Chaff-Faced Ware Cultures) periods in north-western Iran.

\section{Pisdeli (Hasanlu VIII/LC1 Post-Ubaid) period (4500-4300/4200 BC)}

During the mid-5th millennium or slightly later (LC1, Post-Ubaid: 4500-4200 calBC) black-on-buff, so-called Pisdeli culture was gradually replaced throughout the southern, western and northern regions of the Lake Urmia basin. Pisdeli, also known as Hasan- 
lu VIII or middle Chalcolithic, and was first defined at Pisdeli (Dyson, Young 1960) and reported from Hajji Firuz (Voigt 1983) and Hasanlu (Dyson 1958). Interestingly, based on Pisdeli Tepe materials and its sequence, Mary M. Voigt and Robert Dyson (1992. 174) suggested a transition between Dalma and Pisdeli with no gap between these two periods, and proposed that Pisdeli culture developed locally. Most studies of the Pisdeli period relate to the few famous typical sites, including Pisdeli (Dyson, Young 1960), Geoy Tepe (Burton-Brown 1951), Yanik Tepe (Burney 1961a; 1961b; 1962; 1964), and Tepe Gijlar (Belgiorno et al. 1984). Apart from these excavations, various surveys have been brought to light prominent data concerning this period (Belgiorno et al. 1984; Kroll 1984; 1990; 2005).

Recent discoveries in NW Iran have yielded fascinating new information about Pisdeli culture. Excavations at new, well-stratified sites at Kul Tepe Jolfa (Abedi et al. 2014) and Tepe Dava Göz Khoy (Abedi, Omrani 2013) provided new information about the Pisdeli period with new radiocarbon dates. At Kul Tepe Jolfa 3m deposits of Pisadeli period were unearthed. Kul Tepe VII relates to this phase with both painted and unpainted pottery. New radiocarbon dates from Kul Tepe VII give dates around 4500$4300 / 4200$ calBC for the Pisdeli period. The excavation at Dava Göz Khoy has also yielded very strong materials related to this period, with complete typi- cal Pisdeli ware. ${ }^{14} \mathrm{C}$ absolute dating from Dava Göz II suggests the same date for this time span. In the course of recent work, Tepe Ahranjan (Kargar 1994) and Tepe Lavin (Nobari et al. 2012) have provided new information about this period. Apart from the recent excavations mentioned, new surveys have produced new insights and perspectives on the chronological enigma of NW Iran during the Pisdeli period.

Barbara Helwing (2004) suggests a threefold chronological break-down for the Late Chalcolithic in NW Iran and places Pisdeli Tepe in the LCH1 period as the oldest assemblage (= Hasanlu VIII) preceding both Yanik Tepe M, and Geoy Tepe phases N and M and even Gijlar C. She also proposes that the Grey Burnished Ware of Geoy Tepe $\mathrm{N}$ is an early stage of LCH2 and eventually Chaff-faced/Chaff-tempered ware for the developed stage of LCH2. This division was later approved by Michael Danti et al. (2004).

Excavations at Kul Tepe Jolfa and Dava Göz Khoy shed some new light on Pisdeli dates in NW Iran. These dates, accompanied by new recalibrated old samples from the Hasanlu project (Danti et al. 2004), lead us to a comprehensive chronology for the Pisdeli period. New radiocarbon calibrated dates from all Pisdeli-related sites suggested a date of 45004300/4200 calBC for the Hasanlu VIII (LC1, Pisdeli, Kul Tepe VII, Dava Göz II) period.

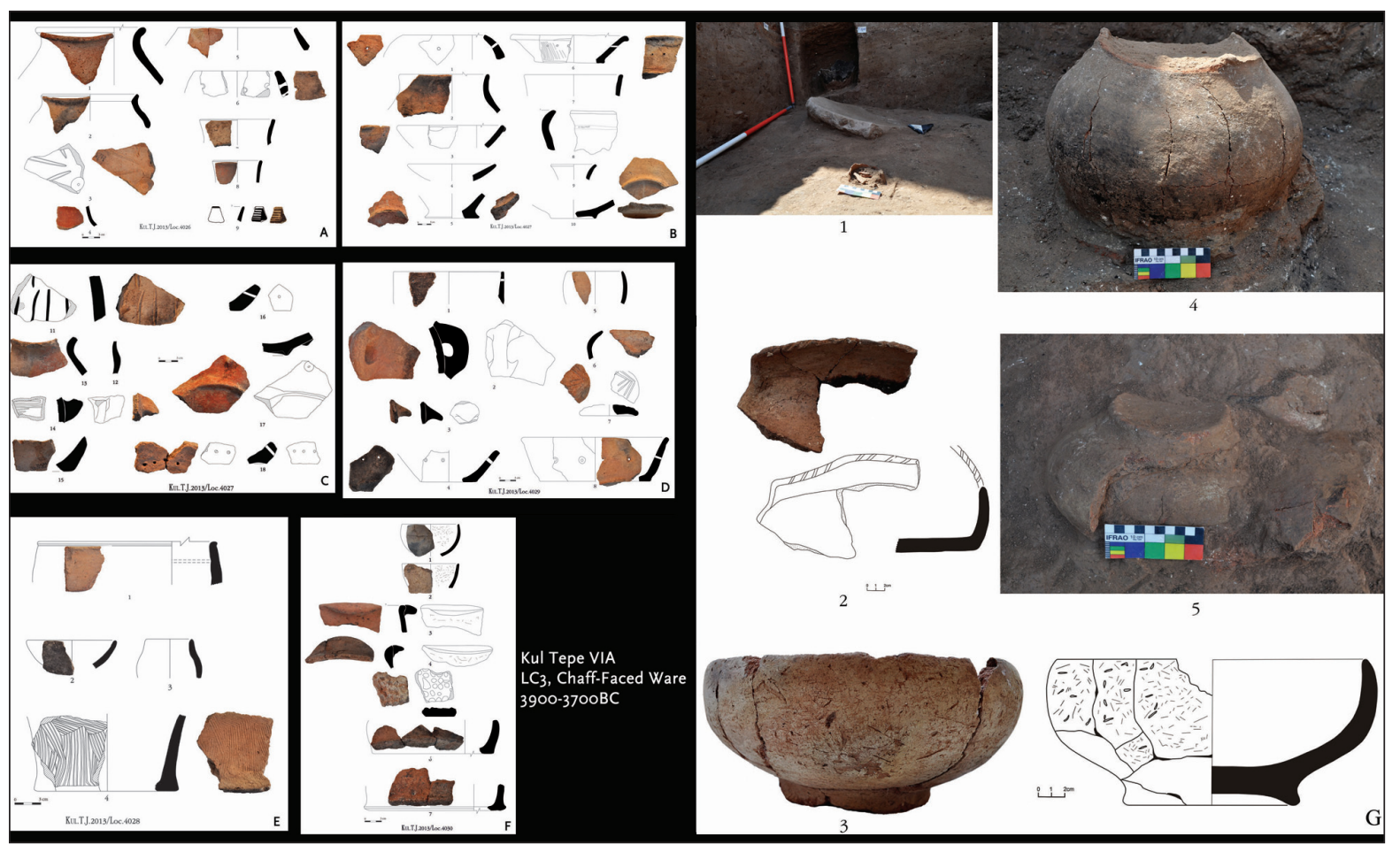

Fig. 7. Kul Tepe VIA (LC3) Chaff-faced pottery. 
LC2; Chaff-faced/Chaff-tempered ware; Kul Tepe VIA/Dava Göz III (4300-3800/3700 calBC)

At present, the Chaff-faced Ware (CFW) or LC2 period is the largest lacuna in our understanding of the developmental chronological sequence in NW Iran. Excavations and published material on CFW or after Pisdeli material in NW Iran are rather scant, and raise many questions. Recently, new data from Kul Tepe Jolfa (Abedi et al. 2014), Dava Göz Khoy (Abedi 2013), Köhne Pasgah Tepesi (Maziar 2010), Dagimentepe Bostanabad (Chaichi, Omrani 2010) have shed some new light on LC2-3 CFW period in NW Iran. Apart from excavations, old and new surveys have provided results regarding the distribution and expansion of CFW phenomena in NW Iran. More than 100 sites were brought to light from all surveys in Iranian Azerbaijan from different districts, such as: Jolfa, Marand, Khoy, Shabestar, Salmas, Urmia, Ushnaviyeh, Naqadeh, Piranshahr, Mahabad, Bukan, Shahin Dezh, Tekab, Malekan, Bonab, Maragheh, Ajabshir, Azarshar, Tabriz, Ahar, Heris, Bostanabad, Hashtrood, and Sarab.

Prior to the Kul Tepe Jolfa and Dava Göz Khoy excavations, only scant materials related to this period had been reported and published (Burton-Brown 1951; Burney 1964; Kroll 1990; 2005; Helwing 2005; Maziar 2010). Recent ${ }^{14} \mathrm{C}$ radiocarbon dates from Kul Tepe Jolfa VIB and VIA and Dava Göz Khoy III suggest a date of $c$. 4200-3700 BC for the LC23 CFW tradition in NW Iran. Recently, fresh dates from adjacent regions - the Southern Caucasus and Northern Mesopotamia - have confirmed this date for CFW (Marro 2010; 2012; Stien 2012; Helwing 2012).

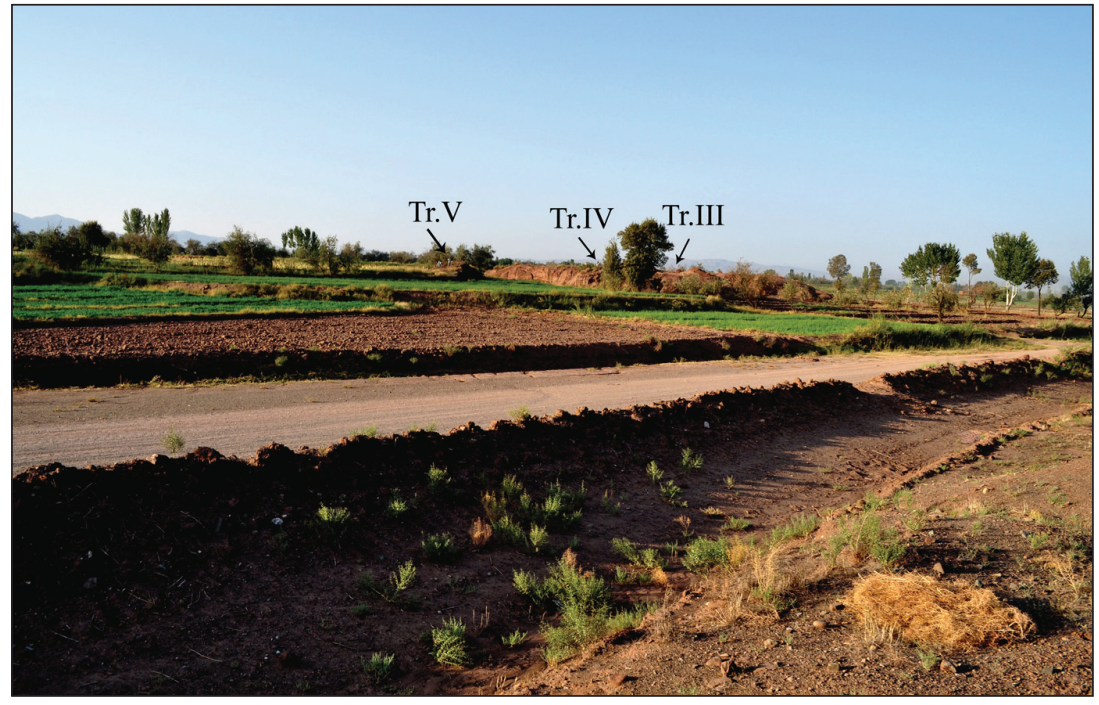

Fig. 8. General view of Dava Göz, View from north-east.
The stratigraphic section at Kul Tepe revealed that 2-5m of strata belong to LC1 and LC2-3, respectively. Kul Tepe VII revealed both black-on-buff painted and unpainted assemblages. Painted samples comprised a small percentage of the pottery repertoire; the situation was the same at Dava Göz, where unpainted ware accounted for the majority of the assemblage.

\section{Discussion}

The Chalcolithic is one of the most important, but also a very ambiguous period in NW Iran. Only sparse and scant studies have been done around the Lake Urmia basin at Geoy Tepe (Burton Brown 1951), Pisdeli Tepe (Dyson, Young 1960), Yanik Tepe (Burney 1961a; 1961b; 1962; 1964) and Tepe Dalma (Hamlin 1975), and some other sites are known from surveys (Pecorella, Salvini 1984; Kroll 1984; 1990) but information is limited to surface collection. The most significant obscurity is due to the lack of accurate ${ }^{14} \mathrm{C}$ dating in chronology of NW Iran. Only scant ${ }^{14} \mathrm{C}$ uncalibrated dates were available from Pisdeli and Tepe Dalma during the 1960s and 1970s and with one or two samples it is impossible to construct a chronology of the region. So the real obstacle is the dramatic lack of absolute dates (with some exception) which makes it impossible to define the chronological extension of the Chalcolithic and build up a solid internal periodisation and properly articulated timeline for regional developments in this phase.

After three decades of stagnation in archaeological activities in NW Iran, valuable work has been done on the prehistoric archaeology of the region in recent years. Almost all excavated sites in the region are around Lake Urmia, while information about the other parts of the region is lacking, and different parts of the region and its prehistory have received unequal attention. While a considerable area of the western and southern parts of the Lake Urmia basin has been explored relatively comprehensively, the eastern and northern parts remain largely archaeological terra incognita. However, the advance of research at well-stratified sites at Kul Tepe Jolfa, 
Dava Göz Khoy with ${ }^{14} \mathrm{C}$ radiocarbon dates has shed some new light on this hitherto poorly understood chronology.

The Dalma culture is one of the most intriguing phenomena of NW and Western Iran. The broad outlines of Dalma material culture are well known by now, and it is renowned for its elaborately decorated pottery. Other aspects of Dalma society, however, are still poorly understood. The chronology and the origin of Dalma society is a matter of much debate, and likewise our insights into Dalma economic or social organisation are generally based on mere speculation.

In the light of the available data, especially the pottery repertoire and recent radiocarbon dates, it demonstrates that the Dalma phenomena or tradition emerged after the Hajji Firuz period (c. 6000-5400 calBC) with a short gap in NW Iran. From this point on, two scenarios are possible for the spread of Dalma in NW Iran; first, we can surmise it as a foreign (alien) imported tradition from outside the NW region (western or southern region), or it can be seen as a local derivative of a previous culture (Hajji Firuz). In this respect, it is felt that Dalma in the Urmia Basin of NW Iran was the ultimate result of a long and locally founded sequence of late Neolithic (Hajji Firuz) development. As mentioned above, with new radiocarbon dates for the Dalma tradition (c. 5000-4500 calBC) it seems likely that some sites can fill this 400-year gap between the two periods, which we regard as a transitional period. A similar conclusion can be drawn from the survey results in the region. Provenance analysis has also shown that all Dalma ceramics were produced locally (Vitali, Henrickson 1987; Tonoike 2009). It seems clear that only pottery production changed during the Dalma period compared with the preceding Hajji Firuz, but not all Dalma sites clearly suggest any marked discontinuity in other aspects of the material culture.
Obsidian analysis in NW Iran (Khademi Nadooshan et al. 2013) indicates that during the Chalcolithic period an extensive and local obsidian trade was practiced by some transhumant or pastoral groups between the Lake Urmai basin and the highlands of the Caucasus. Local regional and inter-regional trade played an important role in the distribution of Dalma culture to adjacent regions. In addition to trade, easy access to main routes, the exploitation of various resources, interaction between lowland settlements and highland pastoral sites by some transhumant or pastoral groups can be considered key factors in the distribution of Dalma culture.

Excavations at Kul Tepe Jolfa and Dava Göz Khoy unravelled the problem of the Chalcolithic of NW Iran after the Dalma period and divided it into two main periods: Pisdeli (LC1 = Kul Tepe VII; Dava Göz II) (4500-4200 calBC) with typical painted pottery (black-on- buff); and the Chaff-Tempered/Chaff-Faced Ware tradition (LC2 and $3=\mathrm{Kul}$ Tepe VIB and VIA; Dava Göz III) (4200-3700 calBC). Recent discoveries in NW Iran make it possible to draw precise conclusions about the final phases of the Late Chalcolithic. The new excavations in the last decade concerning the Chalcolithic in the Southern Caucasus (Ovcular Tepesi, Leyla Tepe) (Achundov 2007; 2011; Müseyibli 2007; Lyonnet 2007b; Lyonnet et al. 2008; 2012; Marro 2010; 2012; Helwing 2012), Eastern Anatolia (Frangipane 2012) and Northern Mesopotamia (Stient 2012) enable scholars to define the chronological range of the Chalcolithic and build up a solid internal periodisation and properly articulated timeline for regional developments in this phase (Marro 2012).

Recent excavations in NW Iran substantiate that postUbaid finds come from settlements whose cultural sequence seemingly develops from a very different, that is, non-Ubaid background. In her most recent publication, Marro (2012) used the term 'post-Ubaid'

\begin{tabular}{|lcccc|}
\hline $\begin{array}{l}\text { Hasnlu } \\
\text { sequence }\end{array}$ & NW chronology & $\begin{array}{c}\text { Kul Tepe } \\
\text { sequence }\end{array}$ & $\begin{array}{c}\text { Dava Göz } \\
\text { sequence }\end{array}$ & Date \\
\hline Hasanlu VII & Kura Araxes II & Kul Tepe IV & - & 3000-2500 calBC \\
\hline- & Proto-Kura Araxes/Kura-Araxes I & Kul Tepe V & - & $3400 / 3500-3000$ calBC \\
\hline- & LC 3, CFW & Kul Tepe VIA & - & $3900-3700 \mathrm{calBC}$ \\
\hline- & LC 2, CFW Horizon & Kul Tepe VIB & Dava Göz III & $4200-3900 \mathrm{cal} \mathrm{calBC}$ \\
\hline Hasanlu VIII (Pisdeli) & LC 1, Black-on-Buff & Kul Tepe VII & Dava Göz II & $4500-4200$ BC \\
\hline Hasanlu IX (Dalma) & Dalma & Kul Tepe VIII & - & $5000-4500$ calBC \\
\hline Hasanlu X (Hajji Firuz) & $\begin{array}{c}\text { Late Neolithic/ } \\
\text { Transitional Chalcolithic }\end{array}$ & Kul Tepe IX & Dava Göz I & 5400-5000 calBC \\
\hline
\end{tabular}

Tab. 2. Chronological table for NW Iran with new chronology from Kul Tepe and Dava Göz. 
for the period from 4500 to 3800 calBC. She divided this phenomenon into 'Ubaid' and 'non-Ubaid' land. She focused on interactions between the lowlands and the highlands, with a reassessment of the available data from a non-Mesopotamian perspective. She used different terms for this spreading phenomena - 'Chaff-Faced Ware oikoumene' (Marro 2010), 'Standardized ware oikoumene' (Marro 2012) - for a period after Ubaid as a result of both interruptions and continuity. She suggests that this widespread expansion of CFW may have been the result of, or is related to the economic and productive sphere (Marro 2012). According to the available data, postUbaid CFW culture in the Southern Caucasus and NW Iran is indeed related to Mesopotamia, but it is not a Mesopotamian culture per se. Rather, the centre of gravity of this culture probably lies between the Upper Euphrates, the Kura Rivers and the Lake Urmia basin. The CFW cultural horizon encompasses the highlands and

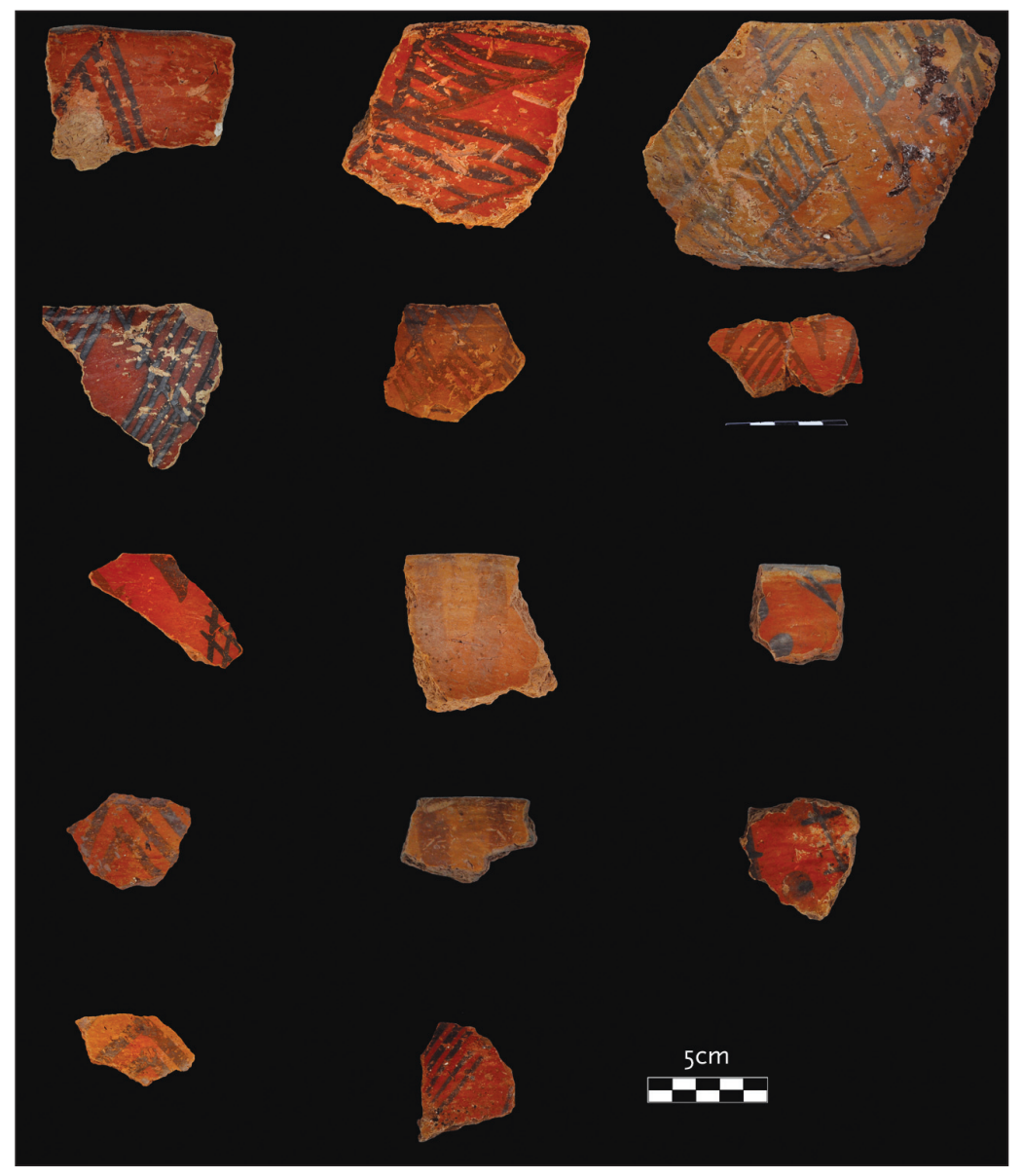

Fig. 9. Typical Late Neolithic / Transitional Chalcolithic pottery from Dava Göz. Upper Mesopotamia, which are thus part of the same oikoumene. However, it should be stressed that the CFW sites attested over this vast territory probably had different functions and were constituents of a complex economic system (Marro 2010).

For the post-Ubaid horizon, six major 'ceramic provinces' or 'cultural provinces' were grouped by Marro (2012): (1) Southern Caucasus; (2) Upper Euphrates province; (3) western Euphrates province; (4) Khabur cultural province; (5) the Balikh region; and (6) the Cilician province. With new excavations in NW Iran (at Kul Tepe Jolfa, Tepe Dava Göz Khoy and Köhne Pasgah Tepesi), a seventh group can be suggested, with typical Pisdeli (LC1 = Kul Tepe Jolfa VII and Dava Göz II) and CFW (LC2 and $3=$ Kul Tepe Jolfa VIB and VIA and Dava Göz III) materials. We think this group is similar to the Southern Caucasus group and is homogeneous in many aspects, but it seems that this was the case only during the LC2 and LC3 periods, while LC1 is absent in most parts of the Southern Caucasus. During LC1, a close relationship can be clearly seen with the Upper Euphrates (sites Norsun Tepe, Korucu Tepe and Tulin Tepe), Khabur
(Gawra XII) and Balikh regions (sites Tell Zeidan LC1 and LC2, and Hammam et-Turkman IVD and VA). Throughout LC2, contacts increased with sites in the Southern Caucasus (Ovcular Tepesi, Leyla Tepe, Mentesh Tepe etc.), Upper Euphrates (Norsun Tepe IIA), Khabur (Gawra XI-IX) and Balikh regions (Tell Zeidan LC2 and Hammam et-Turkman).

Recent excavations show that the development from Pisdeli (LC1 = Kul Tepe Jolfa VII and Dava Göz II) to CFW (LC2 and $3=$ Kul Tepe Jolfa VIB and VIA and Dava Göz III) took place without interruption in NW Iran, which is the case in Balikh and Khabur 'cultural province'.

After the LC 3 period onwards, the CFW tradition was superseded in NW Iran by a widespread expansion of famous Kura-Araxes phenomena, which flourished from the highlands of Transcaucasia and NW Iran. Settlement stratigraphy accomplished with new radiocarbon dates from Kul Tepe Jolfa show that period V (Proto-Kura-Araxes-Kura-Araxes I) with 3400 calBC launch into this period without any interruption. According to the pottery and other materials, 
it seems probable that a transition occurred between the end of the Chalcolithic and beginning of Kura-Araxes culture (Marro 2009). We think this is what occurred in most parts of NW Iran. Only some parts of the southern end of Lake Urmia (Little Zab River) saw a different scenario, with new materials from the middle or late Uruk periods.

However, the Zagros highland region (including the Urmia basin) was clearly not a mo-

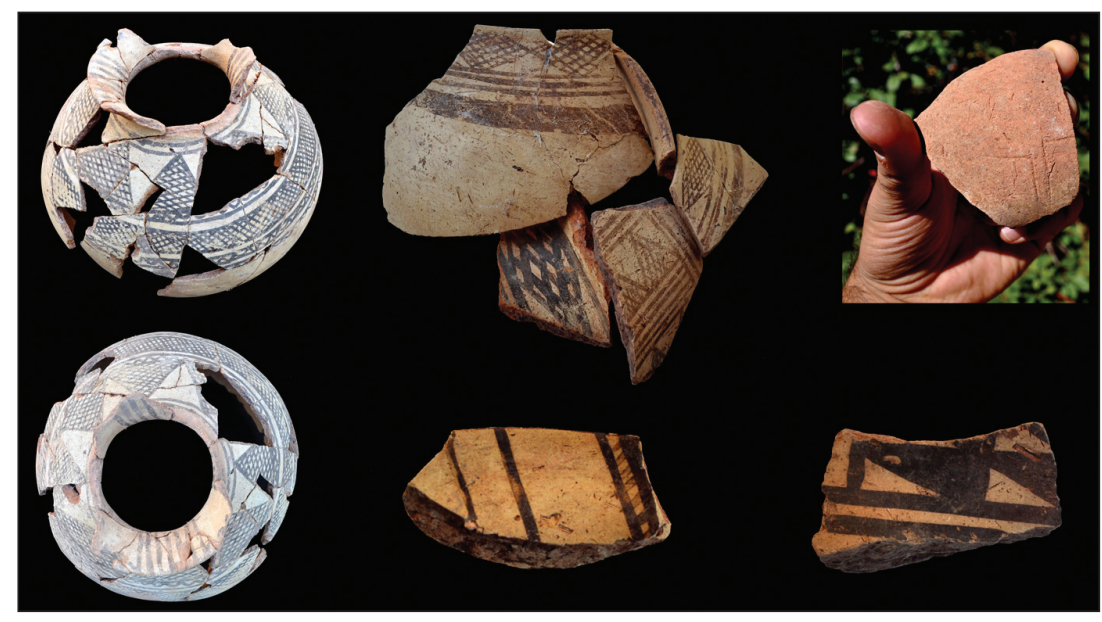

Fig. 10. Typical Late Chalcolithic (Pisdeli Type) pottery from Dava Göz.

nolithic 'Ubaid-related' culture area throughout most of the $5^{\text {th }}$ and the beginning of $4^{\text {th }}$ millennium BC, but rather an environmentally and culturally diverse mosaic with its own strong local ceramic and, presumably, cultural tradition (Henrickson 1983.379).

\section{Conclusion}

Although we are now in a much better position than before to discuss the Chalcolithic period of NW Iran and its subsequent developments, there is still much to be learned about the development and meanings of the material culture and the processes of change and distribution patterns during the $5^{\text {th }}$ millennium calBC.

The available data, new ${ }^{14} \mathrm{C}$ radiocarbon dates from recent excavations in NW Iran, provide a welcome opportunity to rethink $5^{\text {th }}$ and $4^{\text {th }}$ millennium calBC chronology. From what is currently available, we suggest that the Dalma period lasted some 500 years, and dates to between $c$. 5000-4500 calBC. During the mid-5th millennium or slightly later (post-Ubaid: 4500-4200 calBC) black-on-buff, so-called Pisdeli culture (LC1 = Kul Tepe Jolfa VII, Dava Göz II) was gradually replaced throughout the southern, western and northern regions of the Lake Urmia Basin. Late $5^{\text {th }}$ millennium chaff-tempered or chaff-faced ware appears alongside Ubaid-related black-on-buff during LC 2-3 (Kul Tepe VIB and VIA, Dava Göz III: 4200-3800 calBC) in NW Iran.

To sum up, the emerging picture suggests that the CFW system, whose focus was the highlands, was progressively challenged during the $4^{\text {th }}$ millennium in the north as in the south, by the Kura-Araxes and Uruk expansions, respectively. After a period of coexistence with both, the CFW culture was superseded in the highlands by the Kura-Araxes phenomenon, whose driving forces probably had some decisive advantage over its regional neighbours: judging by the importance of metallurgy and mining activities in the Kura-Araxes world, this advantage could have been technological.

\section{References}

Abedi A., Khatib Shahidi H., Chataigner CH., Niknami K., Eskandari N., Kazempour M., Pirmohammadi A., Hoseinzadeh J. and Ebrahimi GH. 2014. Excavation at Kul Tepe of (Jolfa), North-Western Iran, 2010: First Preliminary Report. Ancient Near Eastern Studies 51: 33-167.

Abedi A. 2012. Dava Goz Khoy Excavation: First Preliminary Report. Unpublished report prepared for ICHHTO. (in Farsi)
Abedi A., Omrani B. and Eskandari N. 2009. Kul Tapeh: An Early Bronze Age Site in NW Iran. Antiquity 83(322). Project Gallery. http://antiquity.ac.uk/projgall/abedi322/

Abedi A., Omrani B. 2013. $5^{\text {th }}$ Millennium B.C. in NW Iran: Dalma and Pisdeli Once Again. Conference presentation in A new look at old routes in Western Asia: Rethinking Iran in the $5^{\text {th }}$ millennium BCE. Berlin: May 31-2 June. 
Abdi K. 2003. The early development of Pastoralism in the Central Zagros Mountains. Journal of World Prehistory 17(4): 395-445.

Achundov T. 2007. Sites des migrants venus du ProcheOrient en Transcaucasie. In B. Lyonnet (ed.), Les cultures du Caucase (VIe-IIIe millénaires avant notre ère). Éditions Recherche sur les Civilisations, CNRS Éditions. Paris: 95-122.

2011. Archaeological sites of the Mugan Steppe and prerequisites for agricultural settlement in the South Caucasus in the Neolithic- Eneolithic. Stratum plus 2: 219-236.

Alizadeh K., Azarnoush M. 2003a. Systematic survey of Tepe Baruj: Sampling method and statistical results (Barresi-ye Raveshmand-e Tappe-ye Baruj: Ravesh-e Numunebardari va Natayej-e Amari). Iranian Journal of Archaeology and History 33: 4-25. (in Farsi with English summary)

2003b. Systematic survey of Baruj Tepe: Cultural relationship between the south and the north of the Araxes River (Barasiy-e Ravehsmand-e Tapeh Baruj: Ravabet-e Farhangi-e do soye Rood-e Aras). Iranian Journal of Archaeology and History 34: 3-21. (in Farsi with English summary)

Alizadeh K., Eghbal H. and Samei S. 2015. Approaches to Social Complexity in Kura-Araxes Culture: a View from Köhne Shahar (Ravaz) in Chaldiran, Iranian Azerbaijan. Paleorient 41(1): 37-54.

Alizadeh K., Ur J. A. 2007. Formation and destruction of pastoral and irrigation landscapes on the Mughan Steppe, north-western Iran. Antiquity 81: 148-160.

Azarnoush M., Khatib Shahidi H. and Rezaloo R. 2006. Reviewing the chronology of northwestern Iran in the Bronze Age, case study: Qalla Khosrow. The International Journal of Humanities 13(3): 1-15.

Bakhchaliyev V., Ashurov S. and Marro C. 2009. The Excavations of Ovçular Tepesi (2006-2008): First Results and New Perspectives. In B. Helwing, V. Ioseliani (eds.), Azerbaijan - Land between East and West. Transfer of knowledge and technology during the "First Globalization" of the VIIth-IVth millennium BC. International symposium, Baku, April 1-3 2009. Deutsches Archäologisches Institut, Eurasien-Abteilung. Berlin: 55-62.

Batiuk S. 2005. Migration Theory and the Distribution of the Early Transcaucasian Culture. Unpublished PhD dissertation. University of Toronto. Toronto.

2013. The fruits of migration: Understanding the 'longue dureé' and the socio-economic relations of the
Early Transcaucasian Culture. Journal of Anthropological Archaeology 32: 449-477.

Biscione R., Khatib-Shahidi H. 2006. Italian-Iranian archaeological survey in Eastern Azerbaijan. Studi Micenei ed Egeo-Anatolici 48: 302-306.

Braidwood R., L. Braidwood 1960. Excavations in the Plain of Antioch I. The earlier assemblages, Phases A$J$. The University of Chicago Press. Chicago.

Burney C. A. 1961a. Excavations at Yanik Tepe, northwest Iran. Iraq 23: 138-153.

1961b. Circular buildings found at Yanik Tepe, in north-west Iran. Antiquity 35: 237-240.

1962. The excavations at Yanik Tepe, Azerbaijan, 1961 Second Preliminary Report. Iraq 24: 134-152.

1964. The excavations at Yanik Tepe, Azerbaijan, 1962: Third Preliminary Report. Iraq 26: 54-61.

1970. Excavation at Haftavan Tepe 1968: first preliminary report. Iran VIII: 157-171.

1972. Excavations at Haftavan Tepe 1969: second preliminary report. Iran $X$ : 127-142.

1973. Excavations at Haftavan Tepe 1971: third perliminary report. Iran XI: 153-172.

1975. Excavations at Haftavan Tepe 1973: fourth perliminary report. Iran XIII: 149-164.

Burton-Brown T. 1951. Excavations in Azerbaijan 1948. John Murray. London.

Caneva I., Palumbi G. and Pasquino A. 2012. The Ubaid Impact on the Periphery: Mersin-Yumuktepe During the Fifth Millennium BC. In C. Marro (ed.), After the Ubaid: interpreting change from the Caucasus to Mesopotamia at the dawn of urban civilization (4500-3500BC). Papers from "The Post-Ubaid Horizon in the Fertile Crescent and Beyond", International Workshop held at Fosseuse, $29^{\text {th }}$ June-1 $1^{\text {st }}$ July 2009. Varia Anatolica 27. Istanbul: 353-391.

Crawford H. 1975. Geoy-Tepe 1930. Material in the collection of Fitzwilliam Museu, Cambridge. Iranica Antiqua 9: 49-59.

Danti M. D., Voigt M. M. and Dyson R. H. 2004. The search for the Late Chalcolitic/Early Bronze Age Transition in the Ushnu - Solduz valley, Iran. In A. Sagona (ed.), A view from the high land. Archaeological studies in honor of Charley Burney. Supplement 12. Leuven: 583-615. 
Dyson R. H., Muscarella O. W. 1989. Constructing the chronology and historical implications of Hasanlu IV. Iran 27: $1-27$.

Dyson R. H., Young T. C. Jr. 1960. The Sulduz Valley Iran: Pisdeli Tepe. Antiquity 34: 19-28.

Dyson R. H. 1958. Iran, 1957: Iron Age Hasanlu. The University Museum Bulletin 22(2): 25-32.

1965. Problems of Protohistoric Iran as seen from Hasanlu. Journal of Near Eastern Studies 24: 193-217.

1967. Dinkha Tepe. In Survey of excavations in Iran during 1965-66. Iran 5: 136-137.

1968. The Archaeological Evidence of the Second Millennium B.C. on the Persian Plateau. Cambridge University Press. Cambridge.

Edwards M. 1981. The pottery of haftvan VIB (urmia ware). Iran XIX: 101-140.

1983. Excavations in Azerbaijan (North-Western Iran). Vol. I. Haftavan Period VI. British Archaeological Reports Series 182. Oxford.

1986. Urmia ware, and its contribution in north- western Iran in second millennium B.C. Iran XXIV: 57-77.

Frangipane M. 2001. Centralization processes in Greater Mesopotamia. Uruk 'expansion' as the climax of systemic interactions among areas of the Greater Mesopotamian region. In Mitchell S. Rothman (ed.), Uruk Mesopotamia and its neighbors: cross-cultural interactions and their consequences in the era of state formation. Scholl of American Research. James Currey. Santa Fe: 307-347.

Gopnik H., Rothman S. M. (eds.) 2011. On the High Road. The History of Godin Tepe, Iran. Bibliotheca Iranica: Archaeology, Art and Architecture Series 1. Mazda Publisher in association with the Royal Ontario Museum. Costa Mesa.

Hamlin C. 1975. Dalma Tepe. Iran 13: 111-127.

1974. The early second millennium ceramic assemblage of Dinkha Tepe. Iran 12: 125-153.

Helwing B. 2004. The Late Chalcolithic Period in the Northern Zagros. A Reappraisal of the Current Status of Research. In M. Azarnoush (ed.), Proceedings of the International Symposium on Iranian Archaeology: Northwestern Region. Iranian Center for Archaeological Research. Tehran: 11-24.

2012. Late Chalcolithic craft traditions at the NorthEastern 'periphery' of Mesopotamia: potters vs. smiths in the Southern Caucasus. Origini 24: 193-212.
Henrickson. E. 1983. An Update Chronology of the Early and Middle Chalcolithic of the Central Zagros highlands, western Iran. Iran XXIII: 63-108.

1985. An updated chronology of the early and middle Chalcolithic of the central Zagros highlands, western Iran. Iran XXIII: 63-108.

Henrickson E. F., Vitali V. 1987. The Dalma Tradition: Prehistoric Inter-Regional Cultural Integration Highland Western Iran. Paleorient 13(2): 37-45.

Hojebri Nobari A., Binandeh A., Nestani J. and Vahdati Nasan H. 2012. Excavation at Lavin Tepe Northwest Iran. Ancient Near Eastern Studies 40: 95-117.

Hole F. 1987. Archaeology of the Village Period. In F. Hole (ed.), The Archaeology of Western Iran: Settlement and Society from Prehistory to the Islamic Conquest. Smithsonian Institution Press. Washington D.C.: 29-78.

Ingraham M. L., Summers G. 1979. Stelae and settlements in Meshkin Shahr Plain, northeastern Azerbaijan, Iran. Archäologische Mitteilungen aus Iran 12: 67-101.

Kambakhsh Fard S. 1967. Gozaresh-e Barrasiha va Tahghigat, Gozaresh-e Gaharom, Azarbaijan-e Sharghi, Tehran, Markaz-e Asnad va Madarek-e Sazman-e Mirase-e Farhangiy-e Keshvar. Unpublished report. (in Farsi)

Kargar B. 2005. Qalaychi Zirtu: Mannaean capital. In M. Azarnoush (ed.), Proceedings of the International Symposium on Iranian Archaeology: Northwestern Region. Pizhūhishkadah-'i Bāstān'shināsī, Pizhūhishgāh-i Mīrās-i Farhangī va Gardishgarī. Tehran: 229-245. (in Persian with English summary)

Kargar B., Binandeh A. 2009. A preliminary report of excavations at Rabat Tepe, northwestern Iran. Iranica Antiqua 44: 113-129.

Kearton R. R. B. 1969. Survey in Azerbaijan. In Survey of excavations in Iran, 1967-8. Iran 7: 186-187.

1970. A Study of Settlement in the Salmas Valley, West Azerbaijan, Iran. Manuscript in the files of the Hasanlu Project. University of Pennsylvania. Philadelphia.

Kleiss W., Kroll S. 1979. Ravaz und Yakhvali zwei befestigte Plätze des 3. Jahrtausends. Archäologische Mitteilungen aus Iran 12: 34-47.

Kohl P. L. 2007. The Making Bronze Age of Eurasia. Cambridge University Press. Cambridge.

Kroll S. 1984. Archäologische Fundplätze in Iranisch-0stAzarbaidjan. Archäologische Mitteilungen aus Iran 17: 13-133. 
1990. Der Kultepe bei Marand: Eine chalkolithische Siedlung in Iranisch-Azarbaidjan. Archäologische Mitteilungen aus Iran 23: 59-71.

1994. Festungen und Siedlungen in Iranisch-Azarbaidjan. Untersuchungen zur Siedlungs- und Territorialgeschichte des Urmia-See-Gebietes in vor-islamischer Zeit. Prof. thesis. Ludwig-Maximilans-Universität München. München.

2004. Prehistoric Settlement Patterns in the Maku and Khoy Regions of Iranian Western Azerbaijan. In M. Azarnoush (ed.), Proceedings of the International Symposium on Iranian Archaeology: Northwestern Region. Iranian Center for Archaeological Research. Tehran: 45-53.

2005. Early Bronze Age settlement patterns in the Orumiye Basin. In B. Helwing, A. Özfirat (eds.), Mountains and Valleys. A symposium on highland-lowland interaction in the Bronze Age settlement system of Eastern Anatolia, Transcaucasia and North-western Iran. Archäologische Mitteilungen aus Iran und Turan 37. Dietrich Reimler Verlag GmbH. Berlin: 115-121.

Kromer K., Lippert A. 1976. Die Österreichischen Ausgrabungen am Kordlar Tepe in Aserbaidschan. Mitteilungen der Anthropologischen Gesellschaft in Wien 106: 65-82.

Kushnareva K. Kh. 1997. The Southern Caucasus in Prehistory: Stages of Cultural and Socioeconomic Development from the $8^{\text {th }}$ to the $2^{\text {nd }}$ Millennium $B C$. University Museum Monograph 99. Trans. H. N. Michael. University of Pennsylvania. Philadelphia.

Kushnareva K. Kh., Lisitsyna G. N. 1986. The significant aspects of the establishment and development of a productive economy in the southern and northeastern Caucasus in the sixth to third millennia B.C. Studia Prahistorica 8 . Sofia.

Levine L. D., Young T. C. 1984. A Summary of the Ceramic Assemblages of the Central Western Zagros from the Middle Neolithic to the Late Third Millennium B.C. In J. L. Hout (ed.), Préhistoire de la Mésopotamie. La Mésopotamie préhistorique et l'exploration récent du Djebel Hamrin. Colloques international du CNRS (Paris, 1718 décembre 1984). CNRS Éditions. Paris: 15-53.

Lippert A. 1976. Vorbericht der Österreichischen Ausgraben am Kordlar Tepe in Persisch-Aserbaidschan: Kampagne 1974. Mitteilungen der Anthropologischen Gesellschaft in Wien 106: 83-122.

Lyonnet B. 2007. La culture du Maikop, la Transcaucasie, l'Anatolie orientale et le Proche- Orient: relations et chronologie. In B. Lyonnet (ed.), Les cultures du Caucase,
VIe-IIIe millénaires avant notre ère: leurs relations avec le Proche-Orient. Editions Recherche sur les civilisations. CNRS Éditions. Paris: 133-162.

Lyonnet B., Achundov T., Almamedov K., Bouquet L., Courcier A., Jellilov B., Huseynov F., Loute S., Makharadze Z. and Reynard S. 2008. Late Chalcolithic Kurgans in Transcaucasia. The cemetery of Soyuq Bulaq (Azerbaijan). $A r$ chäologische Mitteilungen aus Iran und Turan 40: 2744.

Lyonnet B., Guliyev F. 2012. Recent Research on the Chalcolithic Period in Western Azerbaijan. In R. Matthews and J. Curtis (eds.), Proceedings of the $7^{\text {th }}$ International Congress on the Archaeology of the Ancient Near East 12 April - 16 April 2010. The British Museum and UCL, London. Harrassowitz Verlag. Wiesbaden: 85-98.

Marro C. 2007. Upper-Mesopotamia and Transcaucasia in the Late Chalcolithic Period (4000-3500 BC). In B. Lyonnet (ed.), Les Cultures du Caucase (VIème-IIIème Millénaires av. n. è.). Leurs relations avec le ProcheOrient. CNRS Éditions. Paris: 77-94.

2009. Late Chalcolithic Ceramic Cultures in the Highlands (4000-3500 BC). In K. Rubinson and A. Sagona (eds.), Ceramics in transitions: Chalcolithic through Iron age in the Highlands. Ancient Near Eastern Studies. Peters Press. Louvain: 9-37.

2010. Where did Late Chalcolithic chaff-faced ware originate? Cultural dynamics in Anatolia and Transcaucasia at the dawn of urban civilization (ca 4500-3500 $\mathrm{BC})$. Paléorient 36(2): 35-55.

(ed.) 2012. After the Ubaid: interpreting change from the Caucasus to Mesopotamia at the dawn of urban civilization (4500-3500BC). Papers from "The PostUbaid Horizon in the Fertile Crescent and Beyond", International Workshop held at Fosseuse, 29th June-1 st $^{\text {th }}$ July 2009. Varia Anatolica 27. De Boccard Editions. Pari.

Marro C., Bakhshaliyev V. and Ashurov S. 2011. Excavations at Ovcular Tepesi (Nakhchivan, Azerbaijan): Second preliminary report: The 2009-2010 Seasons. Anatolia Antiqua 19: 53-100.

Maziar S. 2010. Excavations at Kohne Pasgah Tepesi, the Araxes Valley, Northwest Iran: First Preliminary Report. Ancient Near Eastern Studies 47: 165-193.

Müseyibli N. 2007. Böyük Kəsik. Eneolit dövrü yaşayış məskəni. Bakı. (in Azerbaijani)

Nobari A., Purfaraj A. 2005. The investigation of cultural relationships of Ardebil province with north and north- 
eastern Iran in Neolithic and Chalcolithic periods: Based on archaeological data of Ghosha Tepe in Shahar Yeri. In Abstracts of the International Symposium on Iranian Archaeology: Northern and Northeastern Regions. Iranian Center for Archaeological Research. Tehran: 304.

Oates J. 1983. Ubaid Mesopotamia Reconsidered. In T. C. Young, P. E. L. Smith and P. Mortensen (eds.), The Hilly Flanks and Beyond: Essays on the Prehistory of Southwestern Asia. The Oriental Institute of the University of Chicago. Chicago: 251-282.

Omrani B., Khatib Shahidi H. and Abedi A. 2012. Early Bronze Age, New Migrants and the Beginning of Township in Azerbaijan, NW Iran. Iranica Antiqua XLVIII: 127.

Pecorella P. E., Salvini M. (eds.) 1984. Tra lo Zagros e L'Urmia. Ricerche storiche ed archeologiche nell'Azerbaigian iraniano. Ed. dell'Atene. Rome.

Rothman M. (ed.) 2001. Uruk Mesopotamia and its neighbors: cross-cultural interactions and their consequences in the era of state formation. School of American Research. Santa Fe.

2003. Ripple in the stream: Transcaucasia - Anatolian Interaction in the Murat/Euphrates Basin at the Beginning of the Third Millennium B.C. In A. T. Smith, K. Rubinson (eds.), Archaeology in the Borderlands: Investigations in Caucasia and Beyond. Cotsen Monograph, Book 47. University of California. The Cotsen Institute of Archaeology Press. Los Angeles: 167-84.

Sagona A. G. 1984. The Caucasian Region in the Early Bronze Age. British Archaeological Reports Series 214. Oxford.

Smith A. T., Badalyan R. S. and Avetisyan P. 2009. The Archaeology And Geography of Ancient Transcaucasian Societies. Vol. 1. The Foundations of Research and Regional Survey in the Tsaghkahovit Plain, Armenia. Oriental Institute Press. Chicago.

Solecki R. S. 1969. Survey in Western Azerbaijan. Iran 7: 189-190.

Solecki R. L., Solecki R. S. 1973. Tepe Sevan: A Dalma period site in the Margavar valley, Azerbaijan, Iran. Bulletin of the Asia Institute of Pahlavi University 3: 98-117.
Stein G. J. 2012. The Development of Indigenous Social Complexity In Late Chalcolithic Upper Mesopotamia In the $5^{\text {th }}-4^{\text {th }}$ Millennia BC - An Initial Assessment. Origini XXXIV: 125-151.

Summers G. D. 2013a. The Early Bronze Age in Northwestern Iran. In D. T. Potts (ed.), The Oxford Handbook of Ancient Iran. Oxford University Press. Oxford: 161-178.

2013b. Yanik Tepe, Northwestern Iran: The Early Trans-Caucasian Period: Stratigraphy and Architecture. Peeters. Leuven.

Swiny S. 1975. Survey in Northwest Iran 1971. East and west 25: 77-69.

Talai H. 1983. Pottery evidence from Ahrendjan Tepe, a Neolithic site in Salmas plain, Azerbaijan, Iran. Archaeologische Mitteilungen aus Iran 16: 7-17.

1984. Notes on New Pottery Evidence from the Eastern Urmia Basin: Gol Tepe. Iran XXII: 151-156.

Tonoike Y. 2009. Beyond Style: Petrographic analysis of Dalma ceramics in two regions of Iran. Unpublished PhD thesis. University of Toronto. Toronto.

Vandiver P. B. 1985. Sequential Slab Construction: A Near Eastern Pottery Production Technology, 80003000 BC. Unpublished PhD thesis. Massachusetts Institute of Technology. Massachusetts.

Voigt M. M. 1983. Hajii Firuz Tepe: The Neolithic Settlement. Hasanlu Excavation Reports. Vol. 1. University Museum Monograph 50. University of Pennsylvania. Philadelphia.

Voigt M. M., Dyson R. H. Jr. 1992. The Chronology of Iran, ca. 8000-2000 B.C. In R. W. Ehrich (ed.), Chronologies in Old World Archaeology. $3^{\text {rd }}$ Edition. University of Chicago Press. Chicago: 122-178.

Young T. C., Levine L. D. 1974. Excavations of the Godin projects: second progress report. Royal Ontario Museum. Toronto. 